\title{
NITROGENOUS SUBSTANCES IN SALIVA
}

\author{
2. UREA AND RHODAN \\ YOSHITAME ARAKI* \\ Institute of Physiology, School of Medicine, University of Nagoya
}

As an extension of the previous paper (1), investigations on the contents of urea, ammonia, and rhodan with regard to the rates of salivary secretion will be reported in this paper. According to Barnett and Bramkamp (2) the concentration of urea in parotid saliva corresponds to about $33 \%$ of that in serum at the maximum rate of secretion and about $95 \%$ when secretion is poor. It is well known that rhodan is found in saliva in higher concentration than in any other body fluids $(3,4,5)$, but varies individually and from day to day on the same individual, while it is decidedly high in smokers $(6,7)$. It is also reported its concentration is higher in parotid saliva than in the other salivae (8).

In the present experiments, healthy adults, both male and female, were used, $0.5 \mathrm{cc}$. of 1 per cent pilocarpine was injected subcutaneously and samples of parotid saliva and the other salivae were collected at various phases of secretion in the way described in the previous paper (1). Urea was colorimetrically estimated with xanthydrol, ammonia was estimated by Folin's method and rhodan by Crandall's method (9).

RESULTS

Urea and ammonia nitrogens in parotid saliva. Urea nitrogen in parotid saliva was measured on 8 adults. In 3 cases ammonia was also simultaneously estimated. In all the cases the urea nitrogen level was lower than that in blood serum and showed tendency to vary in inverse proportion to the rates of secretion. This change was however not always very marked and in 3 out of 8 cases there were little change throughout the experiments. The concentration of ammonia was more than 10 times that of serum. Contrary to urea, it varied concomitantly with the rate of secretion,

Fig. 1. Urea and ammonia nitrogen in parotid saliva.

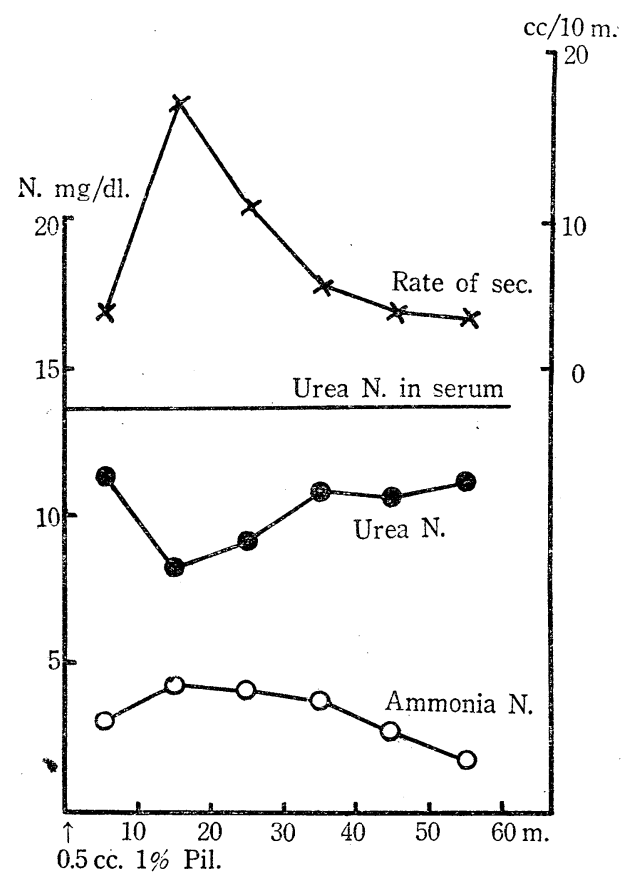

Received for publication October 6, 1951.

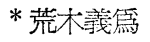


reaching the highest level -3 to $4.8 \mathrm{mg} / \mathrm{dl}$. - at the stage of maximum secretion. It is worthy of note that, in 3 experiments measuring urea and ammonia simultaneously, the sum of both nitrogens in saliva was almost equivalent with the urea nitrogen content in serum throughout various phases of secretion. One example of this kind of experiment is illustrated in fig. 1.

Rhodan content in parotid and other salivae. Experiments were performed on six subjects (two smokers and four non-smokers). The results of experiment on a moderate smoker are given in fig. 2 and an example on a non-smoker in fig. 3. The rhodan content in smokers was considerably higher than that found in non-smokers, the maxima in the latter in the parotid saliva being all below $3 \mathrm{mg} / \mathrm{dl}$. while those in smokers were $6.5 \mathrm{mg} / \mathrm{dl}$. and $7.5 \mathrm{mg} / \mathrm{dl}$. This phenomenon was seen in both the salivae from the parotid and the other glands, but the concentration was higher in the former. Although the concentration of rhodan in saliva considerably varied between smokers and non-smokers and the types of saliva, the features of its change with the rates of secretion, were quite alike. The concentration was high at the begining of secretion and fell concomitantly with the increase of secretion, reaching the lowest level in the phase of maximum secretion and again gradually rose when the secretion subsided. These changes in the concentration were more marked in the parotid saliva than in the other salivae.

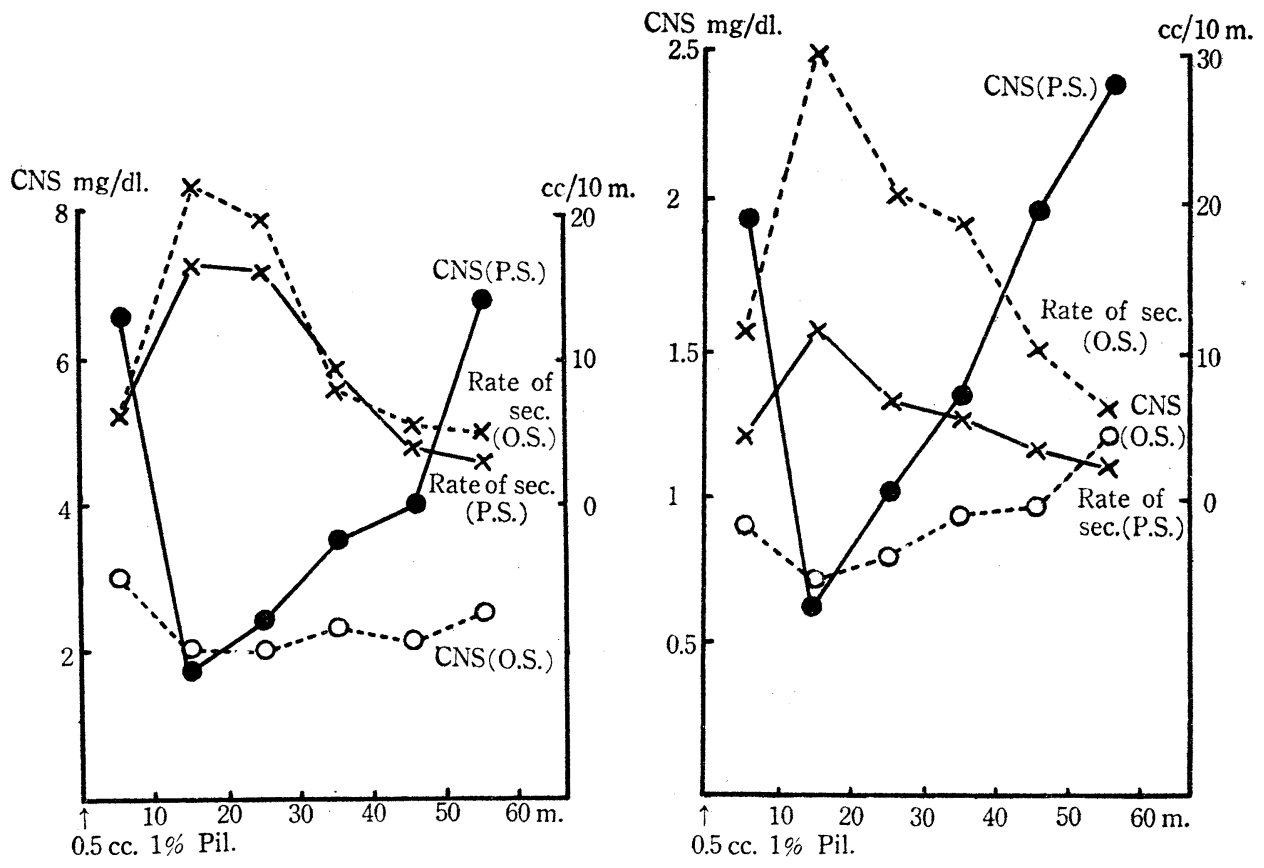

Fig. 2 (left). CNS-nitrogen in parotid and other salivae of the smoker.

P.S. Parotid saliva.

O.S. Other salivae.

Fig. 3 (right). CNS-nitrogen in parotid and other salivae of non-smoker. 
Both in smokers and non-smokers, the rhodan content in serum was so small that it could not be detected by the method used in this experiment, the detectable limit of which was $0.06 \mathrm{mg} / \mathrm{dl}$. Compared with this, the lowest concentration ever found in saliva in this experiment was at least ten times higher.

In 4 cases of experiments $5 \mathrm{mg}$. potassium thiocyanate per $\mathrm{kg}$. were administered 4 hours prior to the experiments. The content of rhodan in serum was markedly raised to about $2 \mathrm{mg} / \mathrm{dl}$. in both smokers and non-smokers. In these cases the concentration of rhodan in saliva was also considerably augmented. Fig. 4 shows one example. This experiment was made on the same individual as in fig. 2. It may be seen that the maximum concentration in parotid saliva is $16.1 \mathrm{mg} / \mathrm{dl}$. in the case in fig. 4 as against $6.5 \mathrm{mg} / \mathrm{dl}$. in fig. 2. The fact that the concentration of rhodan varies with the rates of secretion, and that the concentration in parotid saliva is higher than in the other was also the case in these experiments.

Fig. 4. Effect of $5 \mathrm{mg}$. $\mathrm{KCNS} / \mathrm{kg}$. administered 4 hours prior to experiment.

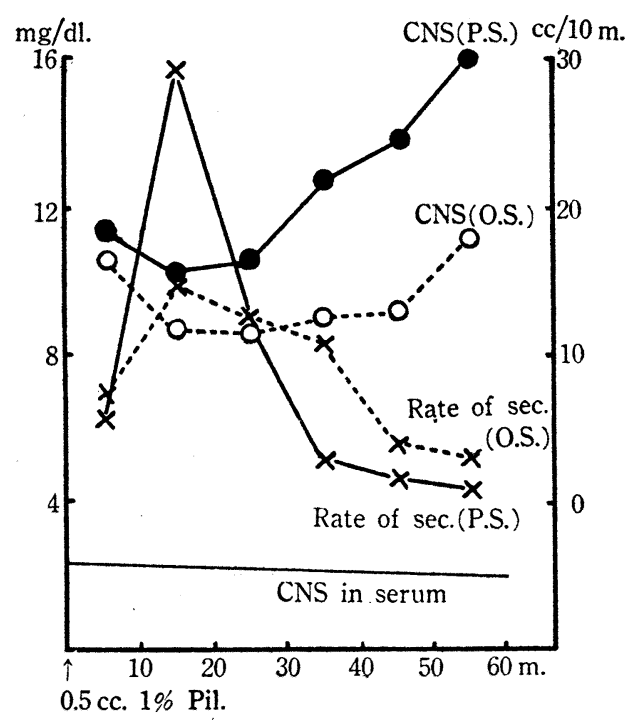

\section{DISCUSSION}

The concentration of urea in parotid saliva was found to be lower than that in serum and varied inversely to the rate of secretion. The results of Barnett (2) were confirmed although the fluctuation during secretion of saliva was not so marked as in his experiments. On the other hand the amount of free ammonia was greater than in the serum and increased in proportion to the rates of secretion. Reports on normal concentration of free ammonia in serum are variant, the highest value being $0.25 \mathrm{mg} / \mathrm{dl}$. As the concentration of ammonia in parotid saliva is $3-5 \mathrm{mg} / \mathrm{dl}$., it is at least more than 10 times that in serum. Hence the ammonia in saliva cannot be considered to have been derived from serum by a simple diffussion mechanism. Further, as previously mentioned, the combined amount of urea and ammonia nitrogen in saliva equals that of urea nitrogen in serum and is unrelated to the rate of secretion. It seems therefore possible that the salivary ammonia is the product of decomposed urea, and it is a question if this occurs within the gland cells or after secretion. In experiments when deproteinisation was undertaken immediately after the collection of saliva, ammonia was found in saliva and no marked change in its amount was detected by determinations after 20 minutes. Accordingly it seems inconceivable that the decomposition takes place so soon 
after secretion of saliva even if it contains urease. From the fact that the urea content is lowest during the period of maximum secretion, or at the height of cell activity, it may be assumed that urea decomposition occurs hand in hand with cell activity. Glick et al. (10) found that free ammonia was secreted from stomach mucosa and concluded that it was separated from urea by urease action in the mucosa cells and that this will be of use for regulating the gastric acidity. In the salivary glands the mechanism may be the same and ammonia is of significance in neutralizing acids formed by cellular metabolism.

Rhodan is a substance resembling halogens in chemical properties and it is believed to exist only extracellularly and be difficult to penetrate through the cell membrane. The secretion of rhodan seen in saliva, however, entirely differs from that of chlorine with regard to the relation with its concentration in serum as well as with the rates of secretion. On the contrary the behaviour of rhodan is similar to that of potassium (11). Much higher concentrations of rhodan than those in serum are always found in saliva. Under ordinary conditions in the body, the cyanates produced from protein decomposition are synthesized to thiocyanates especially in the alimentary canal (12). But it is diffcult to surmise that a similar condition exists in the cells of the salivary gland since cyanate is a respiratory poison.

It may therefore be assumed that the salivary gland cells possess a special function to collect thiocyanates from the circulating blood and discharge it in a higher concentration into saliva. This assumption is supported by the fact that an increase in the concentration of rhodan in serum by administering a certain amount of rhodan causes a rise in its concentration in saliva.

\section{SUMMARY}

The concentration of urea nitrogen in saliva is lower than that in blood and varies in inverse proportion to the rate of secretion. The ammonia nitrogen in saliva is considerably higher than that in blood and is proportionate to the rate of secretion. The total amount of urea plus ammonia nitrogen, is equal to that of urea nitrogen in serum and does not change with the rate of secretion. Ammonia seems to be produced from urea by the activity of gland cells.

The content of thiocyanate in saliva is much higher than that in blood and is in inverse proportion to the rate of secretion. It is suggested that rhodan is taken up from serum by the gland cells.

The experiments were aided by a grant from the Ministry of Education.

\section{REFERENCES}

1. ARAKI, Y. Jap. J. Physiol. $2: 69,1951$.

2. Barnett, G. D. AND G. BRAmKamp. Pro. Soc. Exper. Biol. and Med. 27 : 118, 1929.

3. Munk, J. Virchows Arch. f. Pathol. Anat. u. Physiol. 69: 350, 1877.

4. NECKI, M. Zeitshr. f. Physiol. Chem. 32: 307, 1901.

5. Rosemann, R. Pfïgers Arch. f. Physiol. 118: 495, 1907.

6. LICKINT, E. Zeitshr. f. Klin. Med. $100: 543,1924$.

7. MATHIS, H. Z. Stomat. $30: 1069,1932$. 
8. Schneider, E. C. Am. J. Physiol. $5: 274,1901$.

9. Crandall, L. A. AND M. X. Anderson. Am. J. Digest. and Nutur. 110: 126, 1934.

10. GliCK, D., E. ZACK AND R. W. VON Korff. Am. J. Physiol. 163: 386, 1950.

VON KORFF, R. W. AND D. Glick. Am. J. Physiol. 165: 688, 1951.

Von KorfF, R. W., D. J. Ferguson AND D. Glick. Am. J. Physiol. 165 : 691, 1951.

11. OHARA, K. unpublished.

12. Baumann, E. J., M. Nammette And D. B. Spirson. J. Biol. Chem. 105: 269, 1934. 